\title{
Distribution of Alpha-2-HS-glycoprotein Types in Four East Asian Populations
}

\author{
Kazuo UMETSU1), Mei DING ${ }^{2)}$, Yoshiko HAYASHIDA ${ }^{3)}$, \\ Isao YUASA ${ }^{4)}$ and Tsuneo SUZUKI ${ }^{1)}$ \\ 1) Department of Forensic Medicine, Yamagata University School of Medicine \\ 2) Department of Forensic Serology, Faculty of Forensic Medicine, \\ China Medical University \\ 3) Department of Legal Medicine, Teikyo University School of Medicine \\ 4) Department of Legal Medicine, Tottori University School of Medicine
}

\begin{abstract}
The genetic polymorphism of alpha-2-HS-glycoprotein (AHSG) have been analyzed in Chinese, Korean and remaining Japanese orphan in China populations by isoelectric focusing and immunoblotting technique. Three new variants designated as $A H S G^{*} C 1, A H S G^{*} C 2$ and $A H S G{ }^{*} C 3$ were found. The frequencies of common alleles $\left(A H S G^{*} 1\right.$ and $A H S G^{*}$ ) were approximately the same among East Asian populations.
\end{abstract}

Key Words Polymorphism, Serum alpha-2-HS-glycoprotein (AHSG), New variant, Asian populations

\section{Introduction}

Alpha-2-HS-glycoprotein (AHSG) is present in healthy human serum at concentrations of about $0.60 \mathrm{mg} / \mathrm{ml}$ and is known as negative acute-phase reactant. AHSG is synthesized in the liver and deposited in bone tissue. Its biological function is not yet entirely understood.

The three different types of AHSG were originally described by two-dimensional electrophoresis (ANDERSONand ANDERSON, 1979). Subsequently, one-dimensional isoelectric focusing (IEF) was introduced into AHSG phenotyping (COX and ANDREWS, 1983; UMETSU et al., 1983). So far, 21 AHSG variants have been described (YUASA and UMETSU, 1988;
SALZANO et al., 1990; FUKUMA et al., 1990; FUKUMA et al., 1991). The comparisons of the gene frequencies among the different populations are useful to solve the questions about the nature of migration and microevolution in the human.

This paper presents three new variants designated as $A H S G^{*} C 1, A H S G^{*} C 2$ and $A H S G^{*} C 3$. In addition, the frequencies of AHSG types among population groups of Chinese, Koreans and remaining Japanese orphans in China are reported.

\section{Materials and Methods}

Serum or plasma samples were obtained from four populations: 431 Chinese in Shenyang, 510 Koreans in Seoul, 157 Koreans in Cheju island, 
184 remaining Japanese orphans in China including 100 samples reported in a previous study (UMETSU et al., 1988). Sialidase treatment of the samples was carried out by incubating the mixture of $5 \mu \mathrm{l}$ serum and $20 \mu \mathrm{l}$ sialidase from Arthrobacter ureabaciens (Nakarai tesque, 1 unit/ml, pH 5.0) overnight at room temperature. Desialyzed samples were phenotyped by polyacrylamide gel IEF and immunoblotting as described previously (UMETSU et al., 1986, YUASA and UMETSU, 1988).

\section{Results and Discussion}

Six different alleles were found in the present populations. Among them, three alleles were new variants designated as $A H S G^{*} C 1, A H S G{ }^{*} C 2$ and $A H S G^{*} C 3$ (Fig. 1). $A H S G^{*} 12$ has already been reported previously (UMETSU et al., 1988). In the desialyzed sample, AHSG C1 band located between AHSG 3 and AHSG 1 band; AHSG C2 band, between AHSG $\mathrm{C} 1$ and AHSG 1 band; and AHSG C3 band, slightly anodal of the minor AHSG 6 band. Family studies showing the inheritance patterns are illustrated in Fig. 2. The inheritance mode of the variants corresponds to Mendelian heredity. As shown in Fig, 1, desialyzed products of a AHSG allele includes three bands consisting of one anodal minor, one intermediate major and one cathodal minor band. There are some variants, such as AHSG C1 and

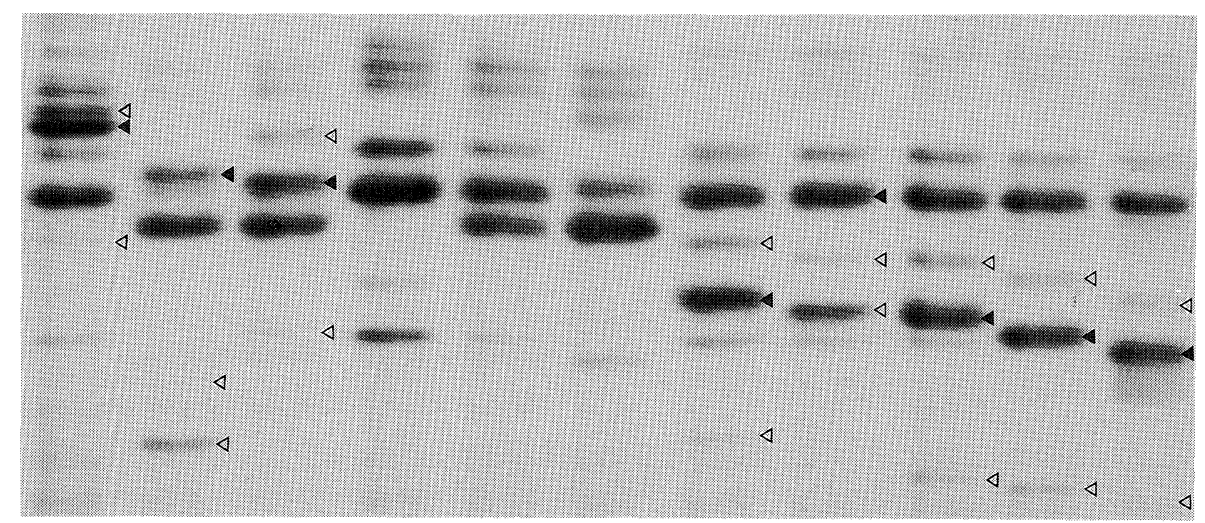

Fig. 1. Desialyzed AHSG patterns detected by immunoblotting followed to polyacrylamide gel IEF. Anode is at the top. Filled and empty triangles indicate major variant and minor variants bands, respectively. From left to right: AHSG 3-1, C1-2, C2-2, 1, 2-1, 2, C3-1, 6-1, 5-1, 12-1 and $15-1$.
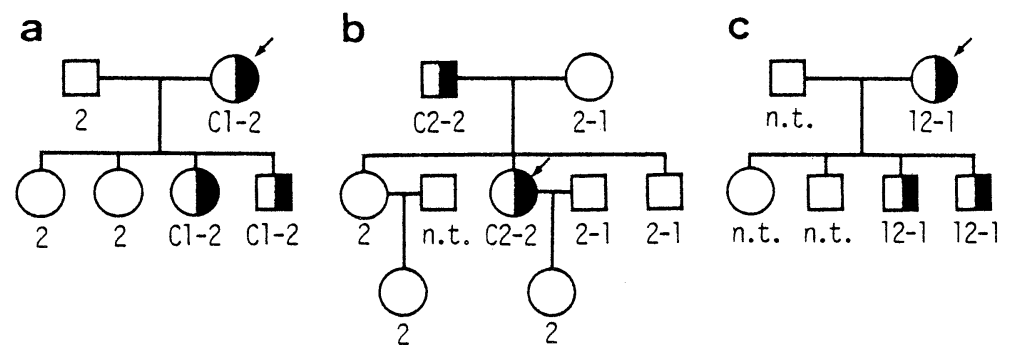

Fig. 2. Pedigrees of families possessing AHSG C1 (a), AHSG C2 (b) and AHSG 12 (c). The proband is indicated by the arrow. 
AHSG 6, which have the exception to this general rule. They have one anodal major and two cathodal minor bands. The exception in the band pattern of these two variants could be explained by a stereochemical specificity of sialic acid or an abnormality of the processing of these variant molecules.

The distributions of the AHSG types and allele frequencies are given in Table 1 . The observed numbers agreed with the expected values calculated on the basis of HARDY-WEINBERG equilibrium (Shenyang, $\chi^{2}=0.5527, \mathrm{df}=1$, $0.30<\mathrm{p}<0.50$; Seoul, $\chi^{2}=1.9536, \mathrm{df}=1$, $0.10<\mathrm{p}<0.20 ;$ Cheju, $\chi^{2}=0.7873, \mathrm{df}=1$, $0.70<\mathrm{p}<0.80$; remaining Japanese orphan in China, $\chi^{2}=0.0011, \mathrm{df}=1,0.95<\mathrm{p}<0.98$ ). The allele frequencies among these four Mongoloid populations are almost the same.

AHSG allele frequencies in several East Asian populations are listed in Table 2. No significant differences of the allele frequencies have been found among Japanese, Korean and Chinese populations $\left(\chi^{2}=9.4437, \mathrm{df}=6,0.10<\mathrm{p}<\right.$ 0.20 ). However, the frequency of $A H S G^{*} l$ in Tsushima islands is a little lower than those obtained from the neighboring populations and that of Cheju island is somewhat higher than those found in other East Asian populations. Interestingly, the distribution of AHSG variants seems to be different from population to population in Japanese. Especially $A H S G^{* 5}$ might be found only in Japanese and the frequency is higher in Okinawa.

\section{Acknowledgements}

This work was supported in part by a Grantin-Aid for Scientific Research on Priority Areas (Prehistoric Mongoloid Dispersals), Ministry of Education, Science and Culture of Japan.

Table 1. Distribution of AHSG types and allele frequencies in four Mongoloid populations

\begin{tabular}{lcccc}
\hline Phenotype & $\begin{array}{l}\text { Shenyang } \\
\text { (Chinese) }\end{array}$ & $\begin{array}{l}\text { Seoul } \\
\text { (Korean) }\end{array}$ & $\begin{array}{l}\text { Cheju is. } \\
\text { (Korean) }\end{array}$ & $\begin{array}{l}\text { Remaining } \\
\text { Japanese orphan } \\
\text { in China }\end{array}$ \\
\hline 1 & 216 & 274 & 93 & 100 \\
$2-1$ & 182 & 191 & 53 & 69 \\
2 & 32 & 45 & 11 & 12 \\
$12-1$ & 0 & 0 & 0 & 1 \\
C1-2 & 0 & 0 & 0 & 1 \\
C2-2 & 1 & 0 & 0 & 0 \\
C3-1 & 0 & 0 & 0 & 1 \\
Total & 431 & 510 & 157 & 184 \\
\hline
\end{tabular}

Allele frequencies

$\begin{array}{lllll}A H S G^{*} 1 & 0.7123 & 0.7245 & 0.7611 & 0.7365 \\ A H S G^{* 2} & 0.2865 & 0.2755 & 0.2389 & 0.2554 \\ \text { AHSG }^{*} 12 & - & - & - & 0.0027 \\ A H S G^{*} C 1 & - & - & - & 0.0027 \\ A H S G^{*} C 2 & 0.0012 & - & - & - \\ A H S G^{*} C 3 & - & - & - & 0.0027\end{array}$


Table 2. AHSG allele frequencies in the East Asian populations

\begin{tabular}{|c|c|c|c|c|c|}
\hline \multirow{2}{*}{ Population (n) } & \multicolumn{4}{|c|}{ Allele frequencies } & \multirow{2}{*}{ References } \\
\hline & $\mathrm{AHSG}^{*} 1$ & AHSG*2 & AHSG*5 & Others & \\
\hline \multicolumn{6}{|l|}{ Japanese } \\
\hline Aomori (400) & 0.7450 & 0.2475 & - & 0.0075 & UMETSU et al., 1987 \\
\hline Yamagata (2050) & 0.7356 & 0.2639 & 0.0005 & - & UMETSU et al., 1984 \\
\hline Yamaguchi (400) & 0.7325 & 0.2675 & - & - & YUASA et al., 1985 \\
\hline Fukuoka (1074) & 0.7165 & 0.2817 & 0.0009 & 0.0010 & FUKUMA et al., 1990 \\
\hline Kochi (1366) & 0.7218 & 0.2782 & - & - & ISHIZU et al., 1986 \\
\hline Okinawa (397) & 0.7670 & 0.2065 & 0.0264 & - & YUASA et al., 1985 \\
\hline Tsushima (514) & 0.6916 & 0.3045 & 0.0010 & 0.0029 & FUKUMA et al., 1990 \\
\hline Goto is. (655) & 0.7221 & 0.2748 & - & 0.0032 & FUKUMA et al., 1991 \\
\hline Japanese $^{1)}(184)$ & 0.7365 & 0.2554 & - & 0.0081 & The present study \\
\hline \multicolumn{6}{|l|}{ Koreans } \\
\hline Seoul $(510)$ & 0.7245 & 0.2755 & - & - & The present study \\
\hline Cheju is. (157) & 0.7611 & 0.2389 & - & - & The present study \\
\hline \multicolumn{6}{|l|}{ Chinese } \\
\hline Shenyang (431) & 0.7123 & 0.2865 & - & 0.0012 & The present study \\
\hline Kaohsiung (199) & 0.7286 & 0.2714 & - & - & YUASA and UMETSU, 1988 \\
\hline
\end{tabular}

1) Remaining Japanese orphan in China

抄 録

東アジア 4 集団における alpha-2-HS-glycoprotein 型の分布

\section{梅津和夫・丁 梅・林田良子・湯浅 勳・鈴木庸夫}

東アジアに属する中国人（潘陽）, 韓国人（ソウル, 済州島）および中国残留日本人孤児の 4 集団におけ る alpha- 2 -HS-glycoprotein (AHSG) 型の分布 頻度を調查した．新しい変異型として，中国人より AHSG C 2 型, 中国残留日本人孤児から AHSG C 1 型と AHSG C 3 型を見出した. また $A H S G * 1$ と $A H S G * 2$ の頻度はいずれの集団においても基本的 には他の近隣集団間とあ大きな差異が見られなかっ たが, 東アジア集団の変異型の出現頻度には集団に よってかなり特徴的な差異があることが示唆された.

\section{References}

ANDERSON, N.L. and N.G. ANDERSON, 1979: Micro- heterogeneity of serum transferrin, haptoglobin and $\alpha_{2}$ HS glycoprotein examined by high resolution twodimensional electrophoresis. Biochem. Biophys. Res. Commun., 88: 256-265.

COX, D.W. and B.J. ANDREWS, 1983: Silver stain immunofixation for $\alpha_{2}$ HS-glycoprotein: A new method for detection of protein heterogeneity. In: STATHAKOS, D. (ed.) Electrophoresis '82., Walter de Gruyter, Berlin, pp. 243-247.

FUKUMA, Y., S. KASHIMURA, K. UMETSU, I. YUASA and T. SUZUKI, 1990: Genetic variation of alpha-2-HS-glycoprotein in the Kyushu district of Japan: description of three new rare variants. Hum. Hered., 40: 49-51.

FUKUMA, Y., S. KASHIMURA, B., NAKANO, K. UMETSU, I. YUASA and I. NAKASONO, 1991: Genetic polymorphism of alpha-2-HS-glycoprotein: four new alleles and allele frequencies in Japanese. Hum. Hered., 41: 89-92.

ISHIZU, H., N. SHOGANO, A. TSUTSUMI, Y. YAMAMOTO, K. KUNITO, S. SEMBA and M. MANABE, 1986: Distribution of $\alpha_{2}$ HS-glycoprotein ( $\alpha_{2}$ HS) types in Kochi Prefecture, Southwestern Japan. Act. Crim. Japon, 52: 173-175. 
SALZANO, F.M., K. UMETSU, I. YUASA, F.L. BLACK and T. SUZUKI, 1990: Isoelectric focusing study in Brazilian Indians - Uncovering variation of ORM, AHSG and IF. Jpn. J. Hum. Genet., 35: 283-290.

UMETSU, K., S. KASHIMURA, N. IKEDA and T. SUZUKI, 1983: Classification of $\alpha_{2}$-HS-glycoprotein ( $\alpha_{2}$ HS) types by isoelectric focusing. Z. Rechtsmed., 91: 33-35.

UMETSU, K., S. KASHIMURA, N. IKEDA and T. SUZUKI, 1984: A new $\alpha_{2}$-HS-glycoprotein allele (AHS*5) in two Japanese families. Hum. Genet., 68: 264-265.

UMETSU, K., I. YUASA and T. SUZUKI, 1986: The polymorphism of desialyzed $\alpha_{2}$ HS-glycoprotein (AHS): isoelectric focusing in $2.5 \mathrm{M}$ urea as a method for identification of genetic variants. Hum. Genet., 73: $372-373$.

UMETSU, K., I. YUASA, M. IKUTA and T. SUZUKI, 1987: Alpha-2-HS-glycoprotein (A2HS) polymorphism in a Japanese population: existence of two new variants. Jpn. J. Human Genet., 32: 263-266.

UMETSU, K., Y. HAYASHIDA, I. YUASA and T. SUZUKI, 1988: On a new alpha-2-HS-glycoprotein variant, AHSG 12. J. Anthrop. Soc. Nippon, 96: 375-377.

UMETSU, K., I. YUASA, T. YAMASHITA, S. SAITO, T. YAMAGUCHI, S.B. ELLEPOLA, T. ISHIDA and T. SUZUKI, 1989: Genetic polymorphisms of orosomucoid and alpha-2-HS-glycoprotein in Thai, Sri Lankan and Paraguayan populations. Jpn. J. Hum. Genet., 34: 195-202.

YUASA, I., T. TAIRA, K. SUENAGA, K. ITO and K. OKADA, 1985: Determination of $\alpha_{2}$-HS-glycoprotein phenotypes by isoelectric focusing and immunoblotting: polymorphic occurrence of $\mathrm{HSGA}^{*} 5$ in Okinawa. Hum. Genet., 70: 32-34.

YUASA, I. and K. UMETSU, 1988: Polymorphism of human $\alpha_{2}$ HS-glycoprotein: characterization and application to forensic hemogenetics. Electrophoresis, 9: 404-410.

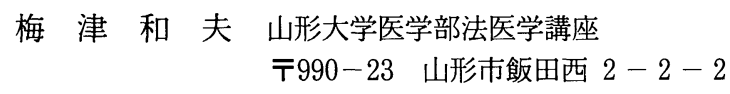

Kazuo UMETSU Department of Forensic Medicine, Yamagata University School of Medicine 2-2-2 Iidanishi, Yamagata 990-23, Japan 